\title{
Reviewer Acknowledgements for Global Journal of Health Science, Vol. 9, No. 12
}

Global Journal of Health Science wishes to acknowledge the following individuals for their assistance with peer review of manuscripts for this issue. Their help and contributions in maintaining the quality of the journal are greatly appreciated.

Global Journal of Health Science is recruiting reviewers for the journal. If you are interested in becoming a reviewer, we welcome you to join us. Please find the application form and details at http://recruitment.ccsenet.org and e-mail the completed application form to gjhs@ccsenet.org.

\section{Reviewers for Volume 9, Number 12}

Dr. Amy E Jetton, Middle Tennessee State University Murfreesboro, United States

António Calha, Polytechnic Institute of Portalegre, Portugal

Dr. Aris Gkoulalas-Divanis, IBM Watson Health, United States

Prof. Arpad Kovacs, University of Kaposvar, University of Pecs, Hungary

Dr. Ayesha Johnson, University of South Florida, United States

Prof. Darampal Dambhare, Mahatma Gandhi Institute of Medical Sciences, India

Dr. Delfina Gabriela Ramos, Polytechnic Institute of Cávado and Ave, Portugal

Dr. Dilek Pirim, Department of Molecular Biology and Genetics, Uludag University, Turkey

Domitila Augusta Huber, Federal University of Santa Catarina, Brazil

Dongxu Fu, University of Virginia, United States

Dr. Evanthia Sakellari, Technological Educational Institute of Athens, Greece

Fengsong Gao, The University of Queensland, Australia

Hülya YARDIMCI, Ankara University, Turkey

Dr. Jingxian Cai, ICSA, ASA, ENAR, United States

José Joaquín Mira, Universidad Miguel Hernández, Spain

Dr. Jose Manuel Hernandez-Padilla, School of Health and Education, Middlesex University, United Kingdom

Mr. Jose R Cordon, Universidad de Cadiz (Spain);SASEMAR(M. Fomento-Spain)-Spanish Goverment, Spain

Dr. Leena Kunnath Chacko, Father Muller College of Nursing, India

Dr. Myo Nyein Aung, (1) Juntendo University, Japan. (2) Boromrajonani College of Nursing, Thailand

Nant Thin Thin Hmwe, University of Newcastle, Australia

Dr. Pedram Iranmanesh, Dentist, Independent Researcher,, Iran, Islamic Republic of

Pi-Ming Yeh, Missouri Western State University, United States

Dr. Raphaële GIRARD, Hospices Civils de Lyon, France

Dr Robert Sloan, Kagoshima University Graduate School of Medical and Dental Sciences, Japan

Dr. Samir Othman, College of Medicine/Hawler Medical University, Iraq

Dr. Sara Melo, Queen's University Belfast, United Kingdom

Dr. Shozab Siddiq Ali, Baptist Health South Florida, United States

Dr Srikrishna Sulgodu Ramachandra, Public Health Foundation of India, India

Dr. Thammanard Charernboon, Thammasat University, Thailand

Dr. Tomás Goicoa, Public University of Navarre, Spain

Prof. Trisha Dunning, Deakin University and Barwon Health, Australia

Dr. Valery Piacherski, Mogilev Regional Hospital, Anesthesiology and Intensive Care of the Mogilev Executive Committee, Belarus 